\title{
Correction to: Tumour draining lymph node-generated CD8 T cells play a role in controlling lung metastases after a primary tumour is removed but not when adjuvant immunotherapy is used
}

\author{
Vanessa S. Fear ${ }^{1,2}$ D . Catherine A. Forbes ${ }^{1,2} \cdot$ Samuel A. Neeve $^{1} \cdot$ Scott A. Fisher $^{1}$. Jonathan Chee ${ }^{1}$. \\ Jason Waithman ${ }^{2}$. Shao Kang Ma ${ }^{1} \cdot$ Richard Lake $^{1}$ - Anna K. Nowak ${ }^{1,3}$. Jenette Creaney ${ }^{1,3}$ - Matthew D. Brown ${ }^{4}$ \\ Christobel Saunders $^{5}$. Bruce W. S. Robinson ${ }^{1,3}$
}

Published online: 5 June 2021

(c) The Author(s) 2021

\section{Correction to: Cancer Immunology, Immunotherapy https://doi.org/10.1007/s00262-021-02934-3}

The original version of this article unfortunately contained a mistake. The given name and family name of authors were swapped.

The correct given name and family name should be:

Vanessa S. Fear

Catherine A. Forbes

Samuel A. Neeve

Scott A. Fisher

Jonathan Chee

Jason Waithman

Shao Kang Ma

Richard Lake

Anna K. Nowak

Jenette Creaney

Matthew D. Brown

Christobel Saunders

Bruce W. S. Robinson
The original article has been corrected.

Open Access This article is licensed under a Creative Commons Attribution 4.0 International License, which permits use, sharing, adaptation, distribution and reproduction in any medium or format, as long as you give appropriate credit to the original author(s) and the source, provide a link to the Creative Commons licence, and indicate if changes were made. The images or other third party material in this article are included in the article's Creative Commons licence, unless indicated otherwise in a credit line to the material. If material is not included in the article's Creative Commons licence and your intended use is not permitted by statutory regulation or exceeds the permitted use, you will need to obtain permission directly from the copyright holder. To view a copy of this licence, visit http://creativecommons.org/licenses/by/4.0/.

Publisher's Note Springer Nature remains neutral with regard to jurisdictional claims in published maps and institutional affiliations.

The original article can be found online at https://doi.org/10.1007/ s00262-021-02934-3.

Vanessa S. Fea

Vanessa.Fear@telethonkids.org.au

1 Institute for Respiratory Health, National Centre for Asbestos Related Diseases, University of Western Australia, Perth, Australia

2 Telethon Kids Institute, Perth, Australia

3 Medical School, School of Biomedical Sciences, University of Western Australia, Crawley, WA, Australia

4 Fiona Stanley Hospital, Murdoch, Australia

5 Division of Surgery, Medical School, University of Western Australia, Perth, Australia 